\title{
Doluluk Oranının 3B Yazıcıda Üretilen TPU ve TPE Numunelerinin Mekanik Özellikleri Üzerine Etkilerinin İncelenmesi
}

\author{
Investigation of the Effect of Infill Rate on Mechanical \\ Properties of TPU and TPE Specimens Produced in 3D \\ Printer
}

\author{
Hatice Evlen * \\ ${ }^{1}$ Karabük Üniversitesi Teknoloji Fakültesi Endüstriyel Tasarım Mühendisliği, Karabük, TÜRKIYE \\ Sorumlu Yazar / Corresponding Author*: hakgul@karabuk.edu.tr

Atıf sekli/ How to cite: EVLEN, H. (2019). Doluluk Oranının 3B Yazıcıda Üretilen TPU ve TPE Numunelerinin Mekanik Özellikleri Üzerine Etkilerinin Incelenmesi. DEUFMD, 21(63), 793-804.

\section{Öz}

Üç boyutlu yazıcı teknolojileri endüstriden savunma sanayine, sağlıktan gıda alanına kadar birçok alanda kendine yer edinmiș durumdadır. Metaller ve kompozitleri, seramikler, çikolata, hamur, sert ve esnek plastikler üç boyutlu yazıcı teknolojisinde en çok kullanılan malzemelerdir. Bu çalışmada, üç boyutlu FDM teknolojisinde en çok tercih edilen TPU ve TPE malzemeler kullanılarak, 4 farklı doluluk oranında (\%40,60, 80 ve 100) ve çizgi kafes (rectilinear) dolgu örüntüsünde tek eksenli çekme ve basma test numuneleri üretilmiștir. Üretilen numuneler üzerinden yüzey pürüzlülügü ve sertlik ölçümleri yapılmıștır. Yapılan çalışmalar sonucunda, göreceli doluluk oranı arttıkça, TPE malzemelerin mekanik özelliklerinin de arttı̆̆ belirlenmiştir. TPU malzemelerde ise \%80 göreceli doluluk oranına kadar mekanik özelliklerin arttığı, buna karşılık göreceli doluluk oranı \%100 olduğunda ise, mekanik özelliklerin azaldığı görülmüștür.

Anahtar Kelimeler: TPU, TPE, çekme, basma, doluluk oranı, sertlik

\begin{abstract}
The three-dimensional printer technologies have established themselves in many areas from industry to defense industry, from health to food. Metals and composites, ceramics, chocolate, paste, hard and flexible plastics are the most commonly used materials in 3D printer technology. In this study, singleaxis tensile and compression test specimens were produced in 4 different infill rate $(40,60,80$ and $100 \%$ ) and rectilinear filling pattern by using the most preferred TPU and TPE materials in three dimensional FDM technology. Surface roughness and hardness measurements were made on the samples. As a result of the studies carried out, it was determined that the mechanical properties of TPE materials increased as the relative infill rate increased. In TPU materials, mechanical properties increased up to $80 \%$ relative infill rate, while the relative infill rate was $100 \%$.
\end{abstract}

Keywords: TPU, TPE, tensile, compression, infill rate, hardness 


\section{Giriş}

Hızlı prototipleme teknolojilerinden biri olan üç boyutlu yazıcılar birçok alanda hayatımıza yerleşmiş durumdadır. Kullanım alanına ve kullanılacak malzeme cinsine göre üç boyutlu yazıcı türleri farklılık göstermektedir. 3B yazıcı teknolojileri, birçok farklı malzeme ve yöntem kombinasyonları kullanılarak oldukça geniş bir alana hitap edebilmektedir. Metal tozları ve SLS (Selective Laser Sintering) yöntemi kullanarak uçak parçaları, kişiye özel implantlar üretilebilir. Bununla birlikte, FDM ve polimer malzemeler kullanılarak döküm modelleri, prototipler, polimer oyuncaklar ve diğer birçok polimer obje üretimi gerçekleştirilebilir [1-5].

Kolay ulașılabilir olușu, diğer cihazlara göre uygun maliyetli oluşu, bakım ve sarf malzeme giderlerinin cazip sınırlarda olușundan dolayı, en çok tercih edilen üç boyutlu yazıcılar FDM (fused deposition method) yazıcılardır. $\mathrm{Bu}$ yazıcılarda en çok kullanılan hammaddeler, termoplastik kökenli malzemelerdir. ABS (akrilonitril bütadien stiren), PLA (polilaktik asit), PET-G (polietilen tereftalat G) VE NAYLON en sik kullanılan termoplastik polimer malzemelerdir. Filament formundaki malzemeler, yüksek sıcaklığa sahip bir nozül yardımı ile eritilerek katmanlar halinde üretilmektedir.

3B yazıcılar ile üretim yapabilmesi için, öncelikle bir 3 boyutlu modele ihtiyaç duyulmaktadır. Herhangi bir üç boyutlu modelleme programında olușturulan parça modeli "STL" veya "obj" uzantılarından birisi ile kaydedilerek, yazdırma parametrelerinin belirlendiği yazıcı arayüz programına aktarılmaktadır. Yazıcı ile model dosyası arasındaki iletișimi sağlayan ve yazdırma parametrelerini belirleyen birçok arayüz programı bulunmaktadır. Cura Engin, Repetier, Slic3r, Kisslice, Skeinforge ve Simplify, genel olarak en çok tercih edilen 3B yazıcı arayüz programlarından bazılarıdır. Ayrıca, piyasada ticari olarak satışı yapılan bazı yazıcıların kendi arayüz programları bulunmaktadır.

3B yazıcı arayüz programlarında, parçanın üretimi için gerekli olan doluluk oranı, dolgu örüntüsü, yazıcı tabla sıcaklığı, nozzlu (yazıcı uç) sıcaklığı, yazıcı uç hızı, katman kalınlığı, katman yüksekliği, katmanlar arası boşluk, yazdırma malzemesinin tanımlanması, çerçeve ve kontür sayısı ve kalınlığı gibi yazıcı parametreleri belirlenebilmektedir. Belirlenen parametrelere göre arayüz programında parça dilimleme işlemine tabi tutulmaktadır. Böylece, arayüz programı tarafından yazdırma işlemi sırasında yazıcı ucun izleyediği yollar ve G kodları oluşturulurken, o parçanın yazımı için kullanılan katman sayısı, toplam filament miktarı ve harcanan süre de hesaplanmaktadır. Ardından yazdırma işlemi başlatılır ve 3B modelleme programında modellenen ürün elle tutulabilir bir formda elde edilmiş olur. Böylece, bir insanın günlerce uğraşıp yapabildiği bir ürün, $3 \mathrm{~B}$ yazıcı sayesinde kısa bir sürede, kalıba ihtiyaç duymadan ve sıfır hata ile üretilmektedir.

Sağlık, spor ve tekstil alanında özellikle esnek polimer malzemelerle yapılan bu ürünler sıklıkla tercih edilmektedir. Sektörde uzun süredir kullanılan esnek malzemelerin 3B yazıcı uygulamalarında kullanılması her geçen gün artmaktadır. $\mathrm{Bu}$ nedenle, piyasada farklı tipte esnek filamentler bulunmaktadır. Bunlardan bazıları; TPU (thermoplastic polyurethane), TPE (thermoplastic elastomer), TPC (thermoplastic co-polyester), SOFT, FLEXIBLE PLA, EMORPH, PCL (polycaprolactone) dir.

TPU, lastik hissi veren ve bu özelliklere sahip esnek bir filamenttir [6]. TPU'nun katı eriyik biriktirme teknolojisinde sağlam, ekonomik ve kullanışlı olması en önemli tercih nedenidir. En büyük avantajı formülasyonunda değişiklik yapılarak birbirinden çok farklı sertlik, yoğunluk ve elastikiyete sahip ürünler elde edilebilmesidir. TPU'nun aşınma direnci yüksektir. Çekme/kopma mukavemeti, yağ dayanımı düşük, ısı dayanımı yüksektir. Yüksek mekanik özellikler barındırır. Geniş sıcaklık aralığında elastikiyete ve düşük elektriksel iletkenliğe sahiptir. Ayrıca TPU'lar geri dönüşümlüdürler, toksik madde içermediklerinden dolayı üretim, uygulama ve kullanım esnasında insan sağlığına zarar vermezler, çevreyi kirletmezler. TPU baskı sonrasında daralma oranı daha hassas bir filamentdir. Bu sebeple hassas ölçüm gerektiren baskılarda daha çok tercih edilir. Extruder sıcaklığı: $240-260^{\circ} \mathrm{C}$ olması gerekir. Tabla sıcaklığı ise $40-60^{\circ} \mathrm{C}$ olmalıdır. Ayakkabı tabanı, esnek refüj dubaları, hayvan küpeleri, terlik, boru, kablo, elektrik malzemeleri, cep telefonu kılıfı, kemer, kapı durdurucuları, yaylar gibi ürünlerle birlikte esneklik ve yüksek așınma dayanımı gerektiren tüm parçaların imalatında kullanılabilir [7-9]. Aynı zamanda TPU biyouyumlu mazlemeler sınıfında sayılabildiği için çeşitli tıbbi uygulamalarda da kullanımına rastlanmaktadır. Bu kadar olumlu özelliğinin yanı sıra TPU malzemelerin düşük termal 
stabilitesi ve mekanik özelliklere sahip olması en büyük dezavantajıdır [10]

TPE (thermoplastic elastomer), TPU filamenti için söylenen mekanik ve elastikiyet özelliklerinin bir çoğu bu malzeme için de geçerlidir. Malzeme ise düşük sertlik değerine sahiptir. Dolayısıyla katmanlı imalat teknolojilerinde kullanılan filament çekme ve itme mekanizmalarında karşılșallan zorluklardan dolayı bütün TPE türleri filament besleme mekanizmasında kullanıma uygun değildir. $\mathrm{Bu}$ nedenle genellikle esnek katmanlı imalat sistemlerinde sertliği 85-95A Shore aralığında değişen ticari TPE filamentle $r$ kullanılır. TPE'nin konvansiyonel termoset kauçuklara kıyasla dezavantajları daha düșük materyal özellikleridir. TPE'ler daha düşük sıcaklık direnci ve daha kötü geri kazanım özelliğine sahiptirler. TPE baskı sırasında toksik bir etki yaratmasa da gidalar ile temas eden tasarımlarda kullanılması tavsiye edilmez [7-9].

3B yazıcılarda baskı hızı, sıcaklık, dolgu örüntüsü ve doluluk oranı, üretilen numunenin mekanik özelliklerini etkileyen parametrelerdir. Literatürde bu parametrelerin etkilerini araștıran ek çok çalıșma bulunmaktadır. Günay ve arkadaşları PLA+ ile yaptıkları çalışmada 3 farklı doluluk oranı, 3 farklı baskı hızı ve 2 farklı tarama açısında tek eksenli çekme test numunesi üretmiş ve parametrelerin PLA+ malzemenin mekanik özellikleri üzerine etkilerini incelemişlerdir. Çalıșmanın sonucunda doluluk oranındaki artışın malzemenin mekanik özelliklerini olumlu etkilerken, hız artışının olumsuz etkilediğini vurugulamışlardır [11]. Chacon ve ark., PLA malzemenin mekanik özelliklerine işlem parametrelerinin etkisini araștırmıșlar ve sonuç olarak baskı hızının artmasıyla dayanım değerlerinin düştüğünü, fakat yüzde uzama değerlerinin arttığını gözlemlemișlerdir [12]. Xiao ve ark. baskı sıcaklığının TPU malzemenin mekanik özelliklerine etkisini inceledikleri çalıșmalarında TPU malzemenin baskı sıcaklığından etkilenen bir malzeme olduğunu, $230^{\circ} \mathrm{C}$ sıcaklığa kadar malzemenin mukavemet değerlerinin arttığını, sıcaklık daha da arttırıldığında mekanik özelliklerin tekrar düșmeye bașladığını belirtmişlerdir [13]. Evlen ve arkadaşları ise doluluk oranının PET ve PLA malzemelerin mekanik özellikleri üzerinde oldukça etkili olduğunu, PET malzemede doluluk oranı arttıkça mekanik özelliklerin de iyileștiğini, fakat nișasta kökenli olan PLA malzemede bu durumun değişebildiğini vurgulamışlardır [14].
Bir parçanın üretiminde tercih edilen doluluk oranı, o ürünün 3B yazıcıda üretilebilmesi için parçanın içine doldurulan malzeme miktarını ifade etmektedir. Doluluk oranı \%1 ile \%100 arasında değiştirilebilmektedir.

Yaygın olarak kullanılan PLA veya ABS (sert) malzemelere göre, esnek filamentlerin (flexible filament) her 3B yazıcıda kullanımı mümkün değildir [2]. Esnek filament için uygun olan 3B yazıcılar; Makerbot Replicator2, Makerbot Replicator 2x, Moment 3B yazıcıdır. Esnek filament kullanımına uygun olamayan $3 \mathrm{~B}$ yazıcılar ise; Ultimaker 1, Ultimaker 2, Ultimaker Extended, Ultimaker 2 Go, Ultimaker 3B yazıcılarda çekmeli extruder teknolojisi olmadığı için esnek filament kullanımına uygun değildir. $\mathrm{Bu}$ nedenle, bu çalışmada, prototip imalatı yapılan FDM tip bir yazıcı ve esnek filamentler kullanılarak, polimer malzemelerin üretimin yapılması amaçlanmıştır [15]. FDM tipi yazıcıda, TPU ve TPE malzemelerden 4 farklı doluluk oranı $(\% 40,60,80,100)$ ve çizgi kafes dolgu örüntüsü kullanılarak çekme ve basma test numuneleri üretilerek, bu polimerlerde göreceli doluluk oranı ile mekanik özellikler arasındaki ilișkinin belirlenmesi hedeflenmiștir.

\section{Materyal ve Metot}

Deneysel çalıșmalarda TPU ve TPE polimerlerin üretimi, FDM tip bir yazıcı kullanılarak, esnek malzeme basımı gerçekleștirilmiștir.

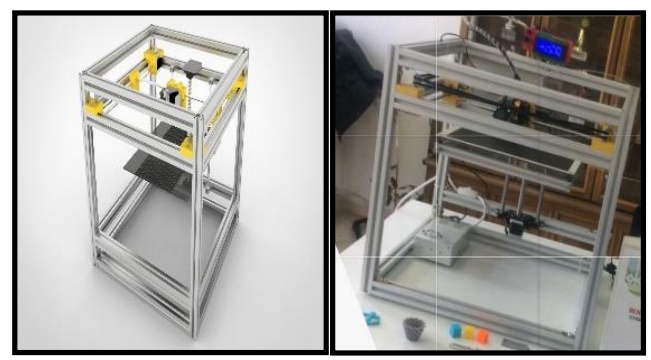

Şekil 1. Prototipi yapılan yazıcının görüntüleri

Kullanılan 3B yazıcının boyutları 560*560*500 mm'dir. Calıșmalarda kullanılan kartezyen tip yazıcının görüntüsü Şekil 1.' de verilmektedir. Yazıcıda 4 adet Nema17 Motor, $30 * 30 \mathrm{~mm}$ sigma profil, $\mathrm{X}$ ve y ekseninde $8 \mathrm{~mm}$ indüksiyonlu mil, $\mathrm{Z}$ ekseninde hareket için $16 \mathrm{~mm}$ bilyalı vidalı mil ve somun, yataklamalar için $12 \mathrm{~mm}$ indüksiyonlu mil, 12V 30Amper güç kaynağı ve Mk8 Extruder kullanılmıștır. Yazıcının baskı alanı ise, $27^{*} 27 * 18 m m$ 'dir.

Yazıcı, X ekseni üzerinde bir eriyik serpme kafasını taşımaktadır. Bu eksen, Y ekseni üzerine 
monte edilmiștir ve $\mathrm{X}$ ekseni ile uyumlu bir şekilde hareket etmektedir. Bu eksende motor, motor miline bağlanan kasnak ve kayıșla beraber kafanın $x$ ve $y$ eksenindeki hareketi sağlanmaktadır. Eriyik serme kafası 2 adet indüksiyonlu mil üzerindeki lineer rulmanlar yardımıyla hareket etmektedir. Z eksenindeki hareket ise, bilyalı vidalı milin setskurla motora bağlanması sonucu olușmaktadır. Z ekseni yataklaması ise, iki adet $12 \mathrm{~mm}$ lik indüksiyonlu millere lmek12luu rulmanlarla yataklanmıștır.

Rep-Rap tipi üç boyutlu yazıcılarda çoğunlukla Arduino geliștirme kartı kullanılmaktadır. $\mathrm{Bu}$ kartlarla entegre çalışan üç boyutlu yazıcı kontrol kartı olarak ise Ramps 1.4 kullanılmaktadır. Rapms kontrol kartındaki giriș ve çıkış pinlerine motorlar, nozzle ısıtıcı fişeği, ısıtıcı tabla, sensörler ve ekran bağlanmaktadır. Üc eksenin kontrolü için birer adet ve motor filamenti itmek için ise bir adet nema 17 step motor ve motorları kontrol etmek için sürücüler kullanılmaktadır. Tasarlanan ve prototip imalatı gerçekleştirilen yazıcıda A4988 motor sürücüsü kullanılmıștır.

Esnek filamentler ile $3 \mathrm{~b}$ yazıcıda üretim yapılabilmesi için yazıcının, çekmeli extrudere sahip olması gerekmektedir. Örneğin arkadan itmeli bir 3B yazıcı modelinde esnek filament yeterince itilemeyeceği gibi aynı zamanda extruder de tıkanmalara yol açmaktadır. $\mathrm{Bu}$ nedenle, çalışmalarda prototip imalatı yapılan sistemde çekmeli ekstruder kullanılmıştır. Ayrıca ekstruderin tıkanmaması için hız ayarının PLA'ya göre daha yavaş olması gerekir.

Yapılan çalıșmalarda, esnek malzeme olarak 0okuma marka TPU ve TPE malzemeler kullanılmıștır.

Deney numunelerinin katı modelleri (standart numune boyutlarına göre), Solidworks 2016 modelleme programında üç boyutlu olarak modellenmiș ve Repetier Host programında dilimleme işlemleri gerçekleștirilerek, yazdırma işlemi tamamlanmıştır. Üç boyutlu yazıcıda numune yazdırma işlemi için kullanılan parametreler Tablo 1.'de verilmektedir. TPU ve TPE malzemelerin mekanik testleri için ISO1798:2008 standardında çekme numuneleri, ASTM395 Metot B standardında basma test numunleri üretilmistir. Cekme testi standart numune boyutları Şekil 2'de verilmektedir. Basma testi için $13 \mathrm{~mm}$ çap ve $6 \mathrm{~mm}$ yükseklikte silindirik numuneler yazdırılmıștır. Basma testi standarda göre numuneler yarı kalınlığına gelene kadar uygulanmış, ardından numune üzerindeki yük kaldırılmıştır.

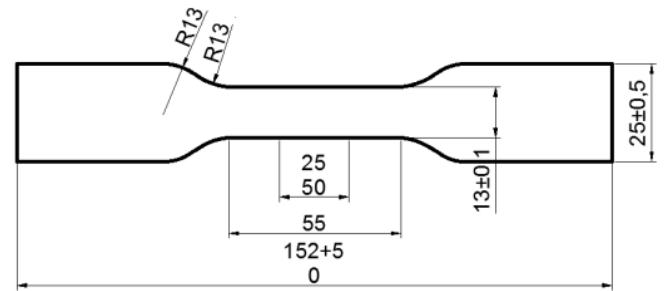

Şekil 2. ISO1798:2008 standardı esnek plastik malzeme çekme numunesi boyutları [16]

Basma testi sonucunda numunelerin $\mathrm{C}_{\mathrm{B}}$ orjinal sapma yüzdeleri;

$$
C_{B}=\left[\left(t_{0}-t_{i}\right) /\left(t_{0}-t_{n}\right)\right] \times 100
$$

eşitliği kullanılarak hesaplanmıştır [17]. Burada, $t_{0}$ numunenin orjinal (ilk) kalınlığ ${ }^{\prime} t_{i}$ numunenin son kalınlığı, $t_{n}$ test esnasında kullanılan ara mesafe çubuğunun kalınlığını ifade etmektedir. Basma testi için 4,5mm kalınlığında ara mesafe çubuğu kullanılmıştır.

Üç boyutlu yazıcı ile üretilen deney numunelerine çekme ve basma testleri yapılmıştır. Deneyler ZWICK/ROEL Z050 test cihazı ile $180 \mathrm{~mm} / \mathrm{dk}$ hızda gerçekleştirilmiştir. Herbir doluluk oranı için üçer adet olmak üzere toplam 12 șer adet numuneye çekme ve basma testi uygulanmıştır. Mekanik testler sonucunda elde edilen verilerin ortalamaları alınıp histogramlarla değerlendirilmiştir. 
DEU FMD 21(63), 793-804, 2019

Tablo 1. Numune yazdırma parametreleri

\begin{tabular}{ccc}
\hline Parametreler & TPU & TPE \\
\hline Tabla Sıcaklığı & $22^{\circ} \mathrm{C}$ & $22{ }^{\circ} \mathrm{C}$ \\
Ekstruder Sıcaklı̆̆ & $240{ }^{\circ} \mathrm{C}$ & $210-230{ }^{\circ} \mathrm{C}$ \\
Doluluk Oranı & $\% 40, \% 60, \% 80, \% 100$ & $\% 40, \% 60, \% 80, \% 100$ \\
Katman Kalınlığı & $0,2 \mathrm{~mm}$ & $0,2 \mathrm{~mm}$ \\
Kullanılan Filament & $\% 40$ İçin: $8258 \mathrm{~mm}$ & $\% 40$ İçin: $8258 \mathrm{~mm}$ \\
& $\% 60$ İçin: $10416 \mathrm{~mm}$ & $\% 60$ Iç̧in: $10416 \mathrm{~mm}$ \\
& $\% 100$ İçin: $12560 \mathrm{~mm}: 14711 \mathrm{~mm}$ & $\% 80$ İçin: $12560 \mathrm{~mm}$ \\
Basım Hızı & $20 \mathrm{~mm} / \mathrm{s}$ & $\% 100$ İçin: $14711 \mathrm{~mm}$ \\
\hline
\end{tabular}

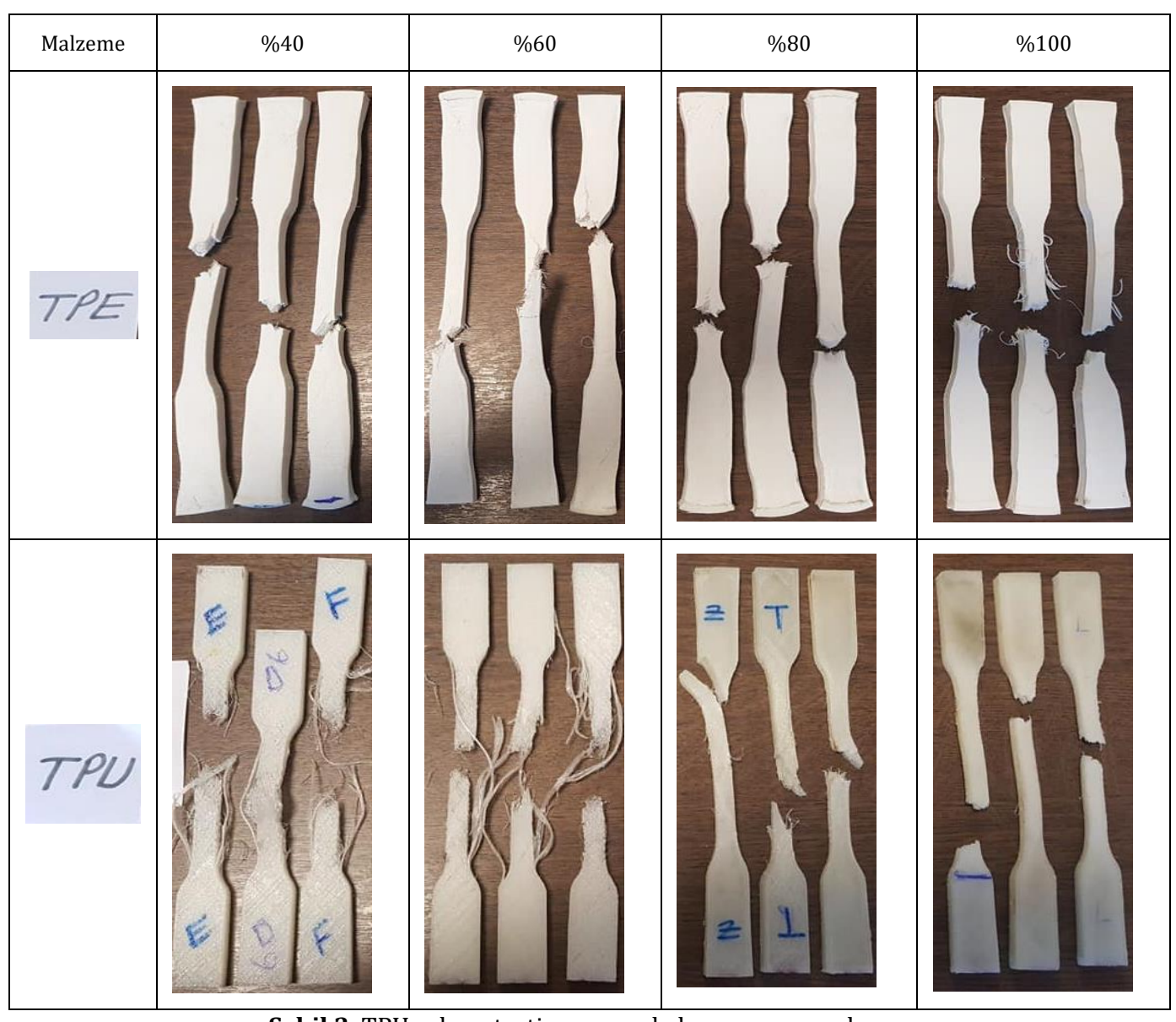

Șekil 3. TPU çekme testi sonucunda kopan numuneler 


\section{Sonuçların Değerlendirilmesi ve Tartışma}

\section{1. Çekme Testi}

Her bir farklı doluluk oranı için üçer adet olmak üzere toplam 12 adet TPU ve 12 adet TPE numuneye çekme testi uygulanmıştır. Çekme testi sonucunda numunelerde meydana gelen hasar, Şekil 3.'te gösterilmiștir. Şekil 3.'te verilen kırık numunelerin görüntüleri incelendiğinde, farklı miktarlarda doluluk oranına sahip TPE malzemelerde, en fazla hasar gören numunelerin \%100 doluluk oranına sahip numuneler olduğu görülebilmektedir. Yine aynı şekilde farklı miktarlarda doluluk oranına sahip TPU malzemelerde ise, en fazla hasarın $\% 40$ ve $\% 60$ doluluk oranına sahip numunelerde olduğu anlașılmaktadır. Çekme testi sonucunda farklı doluluk oranına sahip TPU ve TPE malzemelerin maksimum çekme ve kopma gerilmesi değerleri Şekil 4.'te, \%uzama değerleri ise Şekil 5.'te verilmiştir. Şekil 5.'te verilen maksimum çekme gerilmesi sonuçlarına göre, TPU malzemeden yazdırılan ve $\% 40$ doluluk oranına sahip numunelerin maksimum çekme gerilmesi 2.41 $\mathrm{N} / \mathrm{mm}^{2}$, kopma gerilmesi $1.91 \mathrm{~N} / \mathrm{mm}^{2}, \%$ uzama ise 53,45 'dir. $\% 60$ doluluk oranına sahip TPU malzemelerin maksimum çekme gerilmesi 3,68 $\mathrm{N} / \mathrm{mm}^{2}$, kopma gerilmesi $3,2 \mathrm{~N} / \mathrm{mm}^{2}$ ve $\%$ uzaması 56,88'dir. \%80 doluluk oranındaki TPU numunelerin maksimum çekme gerilmesi 14,21 $\mathrm{N} / \mathrm{mm}^{2}$, kopma gerilmesi $13,8 \mathrm{~N} / \mathrm{mm}^{2}$ ve $\%$ uzaması 86,61'dir. \%100 doluluk oranına sahip TPU numunelerde ise çekme gerilmesi 10,01 $\mathrm{N} / \mathrm{mm}^{2}$, kopma gerilmesi $9,77 \mathrm{~N} / \mathrm{mm}^{2}$ ve $\%$ uzaması 82,22'dir.

TPE malzemelerden 40, 60, 80 ve $\% 100$ doluluk oranlarında yazdırılan numunelerin maksimum çekme gerilmesi değerleri sırasıyla $9,72 \mathrm{~N} / \mathrm{mm}^{2}$, $10,22 \mathrm{~N} / \mathrm{mm}^{2}, 15,49 \mathrm{~N} / \mathrm{mm}^{2}$ ve $17,53 \mathrm{~N} / \mathrm{mm}^{2}$ iken kopma gerilmeleri $9,71 \mathrm{~N} / \mathrm{mm}^{2}, 10,11$ $\mathrm{N} / \mathrm{mm}^{2}, 15,48 \mathrm{~N} / \mathrm{mm}^{2}$ ve $16,3 \mathrm{~N} / \mathrm{mm}^{2}$ olarak belirlenmiștir. Aynı numunelerin \% uzama değerlerinin ise $123,63,126,18,144,61$ ve 136,178 olduğu belirlenmiştir.

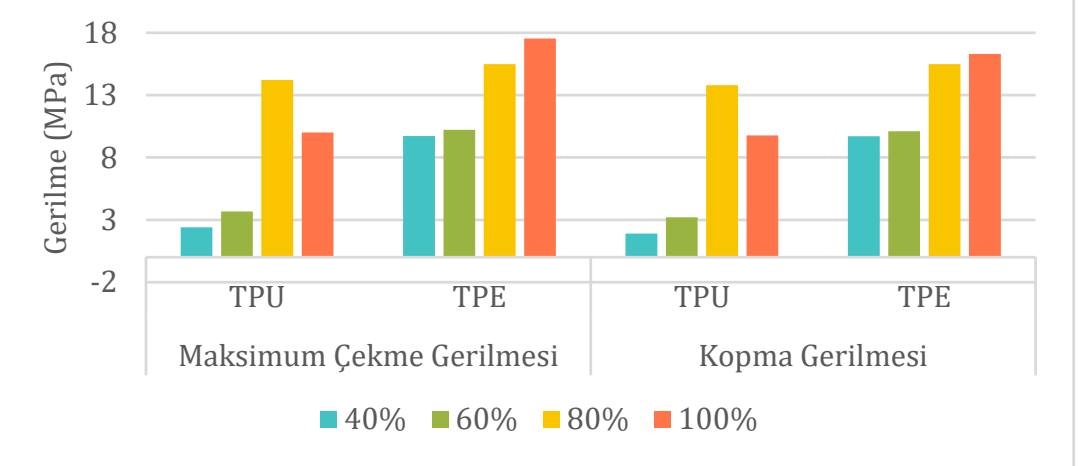

Şekil 4. TPU ve TPE doluluk oranlarına göre maksimum çekme ve kopma gerilmesi değerleri

Şekil 4'te yer alan maksimum çekme ve kopma gerilmesi histogramları incelendiğinde, TPE malzemelerde doluluk oranı arttıkça maksimum çekme ve kopma gerilmelerinin lineer olarak arttığı görülmektedir. Buna karşılık, TPU malzemeler \%80'e kadar çekme ve kopma gerilmelerinde bir artış sergilerken, \%100 doluluk oranına sahip numunelerin hem çekme, hemde kopma gerilmelerinde bir miktar azalma olduğu da görülebilmektedir. Daha önce Xiao ve Gao tarafından yapılan bir çalışmada, $180-190^{\circ} \mathrm{C}$ sıcaklıklarda numune üretimi denenmiș ve bu sıcaklıklarda ekstrüderden malzeme akıșı

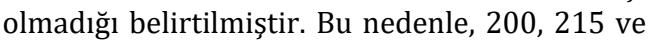
$230^{\circ} \mathrm{C}$ sicaklıklarda üretilen numunelerin çekme testi sonuçları incelenmiștir. Yapılan çalıșmalar sonucunda, TPU'nun sicaklığa duyarlı bir polimerik malzeme olduğunu ve sıcaklığın TPU malzemenin mekanik özellikleri üzerinde oldukça etkili olduğunu ve $\% 100$ doluluk oranında malzemenin mekanik özelliklerinin (çekme gerilmesi, basma gerilmesi, kopma gerilmesi, \%uzama ve \% șekil değișimi) azaldığını vurgulamıșlardır [13]. Yine Sekil 5.'de verilen \% uzama histogramlarında ise, hem TPE hem de TPU malzemelerin \%100 doluluk oranlarında çekme ve kopma uzaması değerlerinin azaldığı görülmektedir. Bu durum numunelerin doluluk oranı arttıkça, gerilmelerinin ve sertlik değerleri arttığı için, sünekliğinin azalmasından kaynaklanmaktadır. 
DEU FMD 21(63), 793-804, 2019

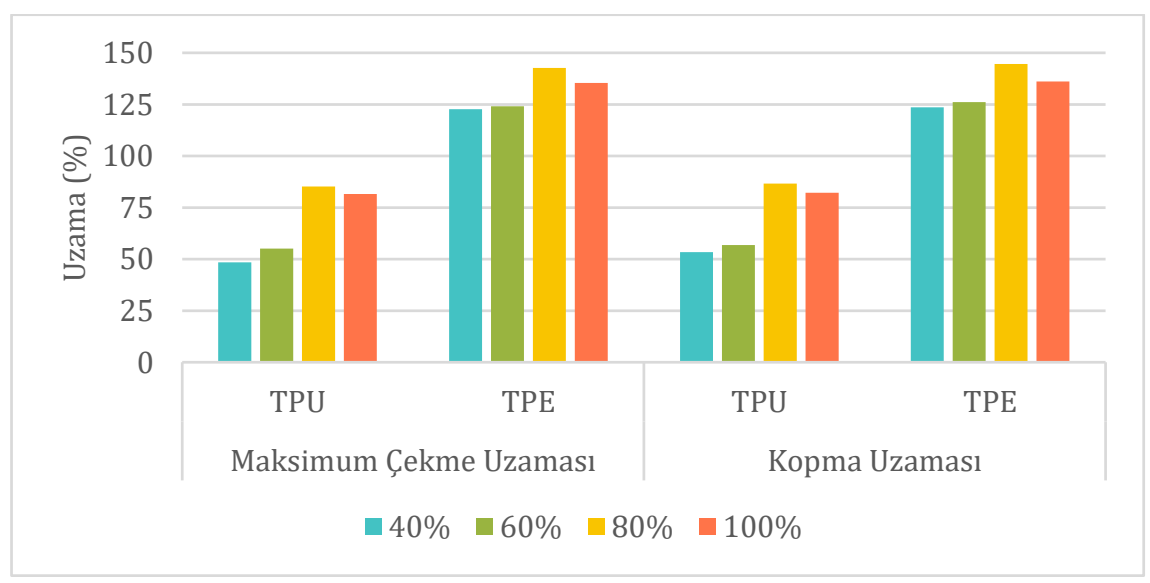

Şekil 5. TPU ve TPE doluluk oranına göre maksimum çekme ve kopma \% uzaması değerleri

\subsection{Basma Testi}

Basma testi uygulanan numunelerin test sonrası numunelerin çap ve boylarında meydana gelen boyutsal değișimler (\% olarak), Şekil 6.'da verilmiştir. TPU malzemelerde en fazla çap değişimi $\% 60$ doluluk oranına sahip numunelerde (\%1,038 oranında) elde edilirken, en fazla boy değişimi ise \%100 doluluk oranına sahip numunelerde $(\% 0,986$ oranında) elde edilmiștir. TPE malzemeden üretilen numunelerde ise en fazla çap değişimi \%40 doluluk oranına sahip numunelerde $(\% 1,002$ oranında) elde edilirken, en fazla boy değișimi ise \%100 doluluk oranına sahip numunelerde $(\% 0,997$ oranında) elde edilmiștir. Bu durum numunelerde doluluk oranı arttıkça, basma testi sonucunda numunelerin enine kesitte yayılma göstermeden boyuna kesitte yı̆̆llma ve kısalmaların olduğunun bir göstergesidir.

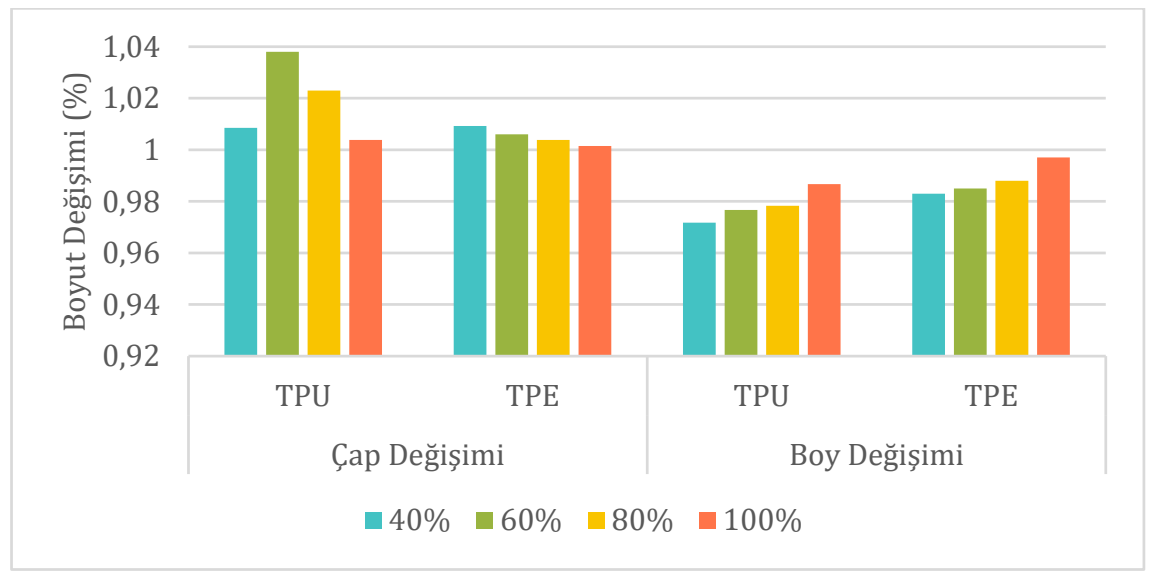

Şekil 6. Basma testi sonucunda numunelerin boyutlarında meydana gelen \% değişim oranları

Şekil 7.'de maksimum basma ve kopma gerilmeleri verilmiștir. Şekil 7 de verilen sonuçlar incelendiğinde, TPE malzemelerden üretilen numunelerde doluluk oranıyla birlikte numunelerin gerilmelerinin de arttığ gözlenmektedir. En büyük maksimum basma gerilmesi değeri (\%100 doluluk oranına sahip numunelerde) 17,533 MPa ve en küçük basma gerilmesi $(\% 40$ doluluk oranına sahip numunelerde) 9,72 MPa olarak elde edilmiştir. Bununla birlikte, en büyük kopma gerilmesi
(\%100 doluluk oranında) 16,3 MPa, en küçük kopma gerilmesi değeri ise (\%40 doluluk oranına sahip numunelerde) 9,71 MPa olarak belirlenmiștir. Genel olarak TPE numunelerde doluluk oranına paralel olarak basma ve kopma gerilmelerinde artış olduğu görülmektedir. Ancak TPU malzemeden üretilen numunelerde en büyük basma ve kopma gerilmesi değerleri $\% 80$ doluluk oranına sahip numunelerde sırasıyla $14,21 \mathrm{MPa}$ ve $13,8 \mathrm{MPa}$ olarak belirlenmiştir. Doluluk oranı \%100 olduğunda 
DEU FMD 21(63), 793-804, 2019

ise, basma ve çekme gerilmeleri tekrar azalma eğilimi sergilemektedir. TPU ve TPE malzemelere uygulanan basma testlerinin sonuçları, Șekil 4.'te yer alan çekme ve kopma gerilimleri ve Şekil 5.'te yer alan \% uzama değerleriyle de uyumlu olduğu anlaşılmaktadır.

TPE malzeme ile üretilen numunelere uygulanan mekanik testler sonucunda beklendiği gibi doluluk oranı arttıkça numunelerin mekanik özellikleri de artmaktadır. Ancak TPU malzemede \%80 doluluk oranına kadar gerilme değerleri artarken, \%100 doluluk oranında mekanik değerlerin tekrar azaldığ görülmektedir. Daha önceki bir çalışmada, TPU malzeme $230^{\circ} \mathrm{C}$ sıcaklığın üzerine çıkıldığında, TPU'nun ekstrüder sicaklı̆̆ından olumsuz etkilendiği ve mekanik özelliklerin azaldığı veya tutarsızlık gösterdiği belirtilmiștir [18].

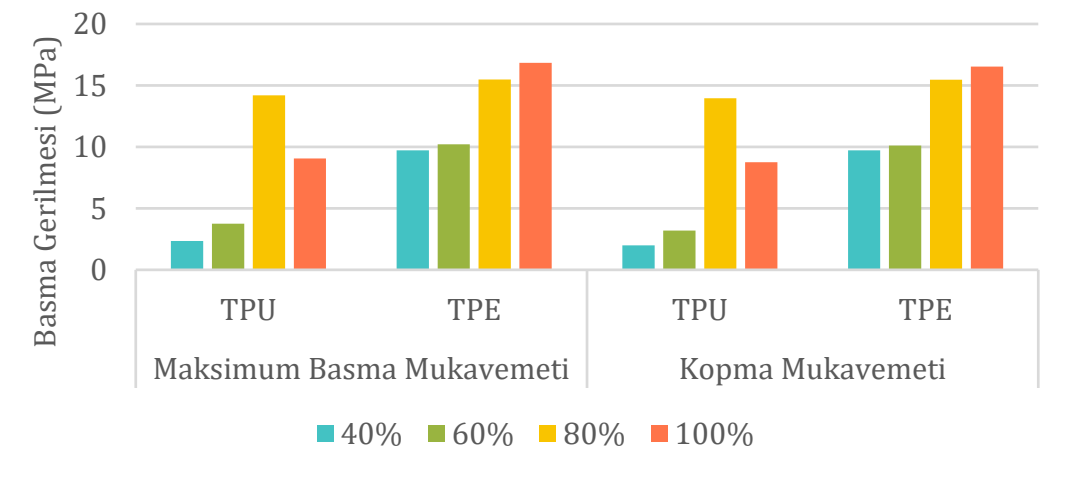

Şekil 7. Doluluk oranlarına göre TPU ve TPE malzemelere ait basma ve kopma gerilmeleri

Basma testi sonucunda elde edilen \% şekil değișimi sonuçları, Șekil 8.'de verilmektedir. TPU ve TPE numunelerde doluluk oranı arttıkça, maksimum basma ve kopma gerilmesindeki \% șekil değișimi artmaktadır. TPE numunelerde sadece \%100 doluluk oranında, \% şekil değişimi oranı azaldığı anlaşılmaktadır. Aynı malzemenin çekme testleri sonucunda elde edilen \% uzama grafiğinde de aynı durum söz konusudur (Şekil $5)$.

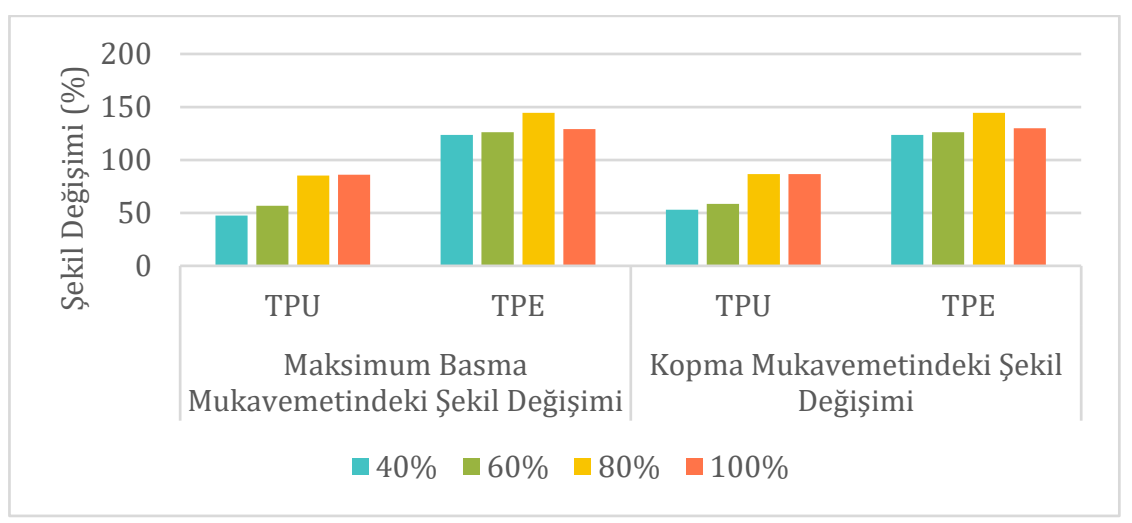

Şekil 8. Doluluk oranına göre basma testi sonrası oluşan \% șekil değișimi histogramları

Daha önce yapılan bazı çalışmalarda FDM yazdırma teknolojisi, anlık olarak malzemenin ısıtılıp plastik deformasyona uğratılması olarak tanımlanmaktadır. Ancak, ekstrüzyon sıcaklığı arttıkça akış hızının da arttığı, artan akış hızının katmanlar arasında yapıșma olmadan yeni katmanın serilmesine sebep olduğu ifade edilmektedir. $\mathrm{Bu}$ durumun da malzemede adhezyon gerçekleșemeden önce meydana gelen üstüste yı̆̆ılmadan dolayı, sertlik ve gerilme değerlerinde düşüşe sebep olduğu belirtilmektedir $[14,18,19]$. TPE ve TPU numunelerin 4 farklı doluluk oranına bağlı olarak orjinal sapma yüzdeleri, Şekil 9'da verilmektedir. 
DEÜ FMD 21(63), 793-804, 2019

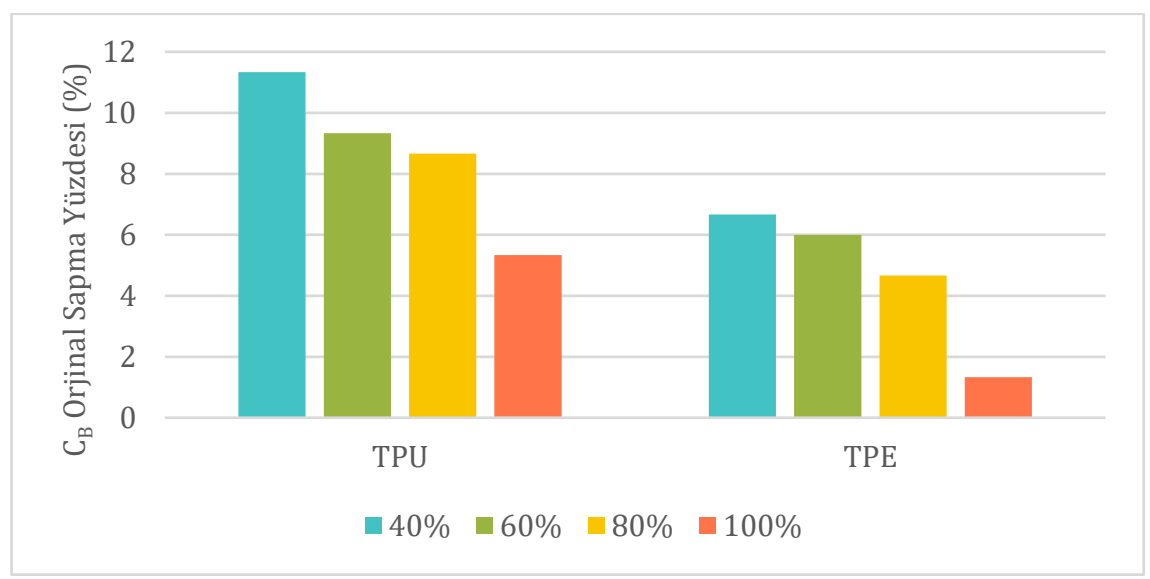

Şekil 9. Doluluk oranlarına göre $\mathrm{C}_{\mathrm{B}}$ orjinal sapma yüzdeleri

Basma testi sonucunda farklı doluluk oranına sahip numunelerin yükseklik değişimlerine göre hesaplanan $\mathrm{C}_{\mathrm{B}}$ orjinallik sapma yüzdeleri (Eşitlik 1'e göre) Şekil 9.'da verilmektedir. CB orjinallik sapma yüzdelerine göre (basma testlerinde), numunelerin yükseklik ölçümlerine göre en fazla boyutsal sapma TPU malzeme (\%40 doluluk oranında) \%11,33 olarak hesaplanırken, en az sapma (\%100 doluluk oranında) \%1,33 olarak hesaplanmıştır. $\mathrm{Bu}$ sonuçlara göre, TPE malzemenin \% șekil değișimi oranının daha fazla olduğu (Şekil 8), fakat bu malzemelerin TPU malzemeye göre daha az hata payı ile ve daha güvenilir sonuçlar elde edilebildiği söylenebilir. Ayrıca üç boyutlu yazıcı ile gerçekleştirilen numune üretiminde numunelerin doluluk oranı arttıkça mekanik testlerde numunelerin kuvvetten daha az etkilendiğini ve orjinal boyutlardan daha az sapma gösterdiğini ifade etmektedir.

\subsection{Sertlik ölçümü}

Şekil 10'da TPU ve TPE malzemelerin Shore A sertlik değișimleri verilmektedir. Sertlik değișimi sonuçları incelendiğinde, $\% 40,60,80$, 100 doluluk oranına sahip TPU numunelerin sertlikleri sırasıyla $12,9,13,9,14,5$ ve 14,1 Shore A olarak elde edilirken, TPE numunelerinin sertlikleri ise sırasıyla $13,7,13,8,14$ ve 15 Shore A olarak elde edilmiştir. Şekil 10 'da verilen sertlik değișimlerinden de anlașıldığı gibi, TPU malzemede \%80 doluluk oranında sertlik değeri ani olarak artmakta ve, \%100 olduğunda doluluk oranı azalmaktadır. TPE malzemelerden elde edilen numunelerin sertlik sonuçlarında ise doluluk oranı arttıkça, numunelerin sertliği de artmaktadır. $\mathrm{Bu}$ durum, literatürü destekler niteliktedir [20]. Sertlik ölçüm sonuçları, numunelere uygulanan basma ve çekme testi sonuçlarını destekler niteliktedir. Numunelerin sertliği arttıkça maksimum çekme ve basma gerilmeleri de artmakta, \% uzama ve \%şekil değişimi değerleri ise azalmaktadır. Bu sonuçlar, numunelerin doluluk oranı arttıkça malzemenin süneklikten gevrekliğe geçtiğini göstermektedir. 
DEÜ FMD 21(63), 793-804, 2019

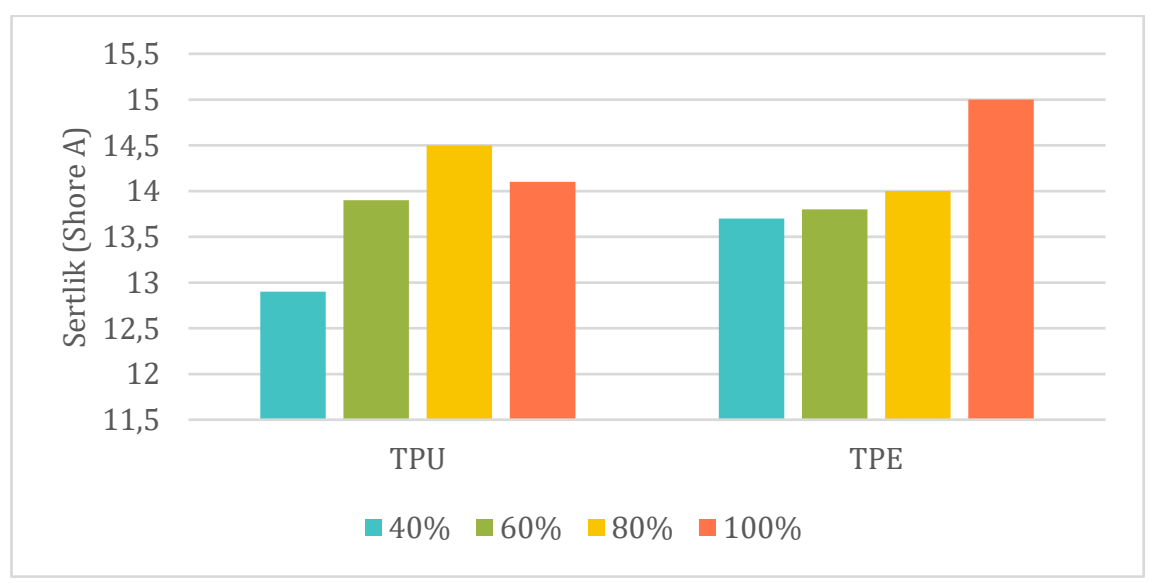

Şekil 10. TPU ve TPE malzemelerin Shore A sertlik ölçüm sonuçları

\subsection{Yüzey Pürüzlülüğü Ölçümü}

Şekil 11'de 4 farklı doluluk oranında TPU ve TPE malzemelerden yazdırılan numunelerin yüzey pürüzlülük $(\mathrm{Ra})$ sonuçları verilmektedir. Yüzey pürüzlülüğü ölçüm sonuçlarına göre, TPU numunelerde en büyük pürüzlülük değeri $\% 40$ doluluk oranındaki numunelerde 1,085 Ra olarak elde edilirken, en küçük pürüzlülük değeri \%100 doluluk oranına sahip numunelerde 1,0038 olarak ölçülmüștür. TPE numunelerde en büyük pürüzlülük değeri $\% 40$ doluluk oranına sahip numunelerde 1,0092, en küçük pürüzlülük değeri ise $\% 100$ doluluk oranına sahip numunelerde 1,0015 olarak elde edilmiştir. Numunelere uygulanan çekme ve basma testleri, sertlik ölçümleri ve yüzey pürüzlülük ölçümleri birlikte değerlendirildiğinde, numunelerin doluluk oranı arttıkça yüzey pürüzlülüğünün azaldığı, TPU ve TPE malzemelerin mekanik özelliklerinin ise iyileştiği anlaşılmaktadır.

Yüzey pürüzlülüğü ve mekanik özellikler arasındaki ilișkinin incelendiği bazı çalışmalarda, FDM yöntemiyle 3B yazıcılarda üretilen parçaların doluluk oranı arttıkça malzemenin gerilme değerlerinin arttığı ifade edilmektedir. Bununla birlikte, artan doluluk oranının yazıcı nozul ucunun izleyeceği yol sayısını arttırdığı, dolayısıyla polimerik malzemelerin yüzey pürüzlülüğünün de arttığl belirtilmektedir [19, 21]. Yine aynı çalışmalarda, Ra değerindeki artış nedeniyle meydana gelen çentik etkisinin, malzemenin mekanik özelliklerini olumsuz etkilediği de belirtilmektedir. Bu çalışmada, doluluk oranının artmasıyla Ra değerinin azaldığı gözlenmiştir.

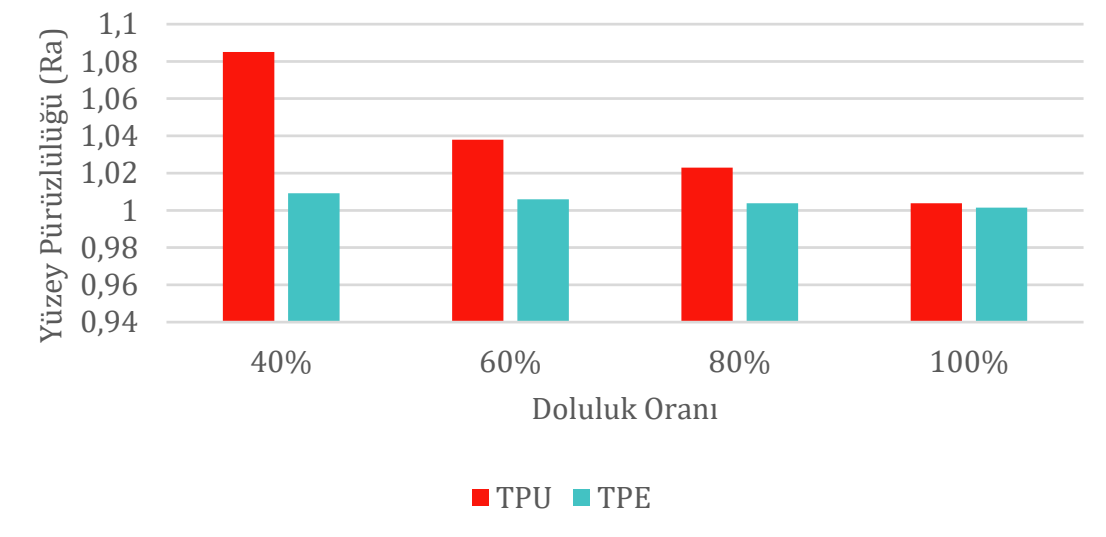

Şekil 11. Yüzey pürüzlülüğü ölçüm sonuçları 


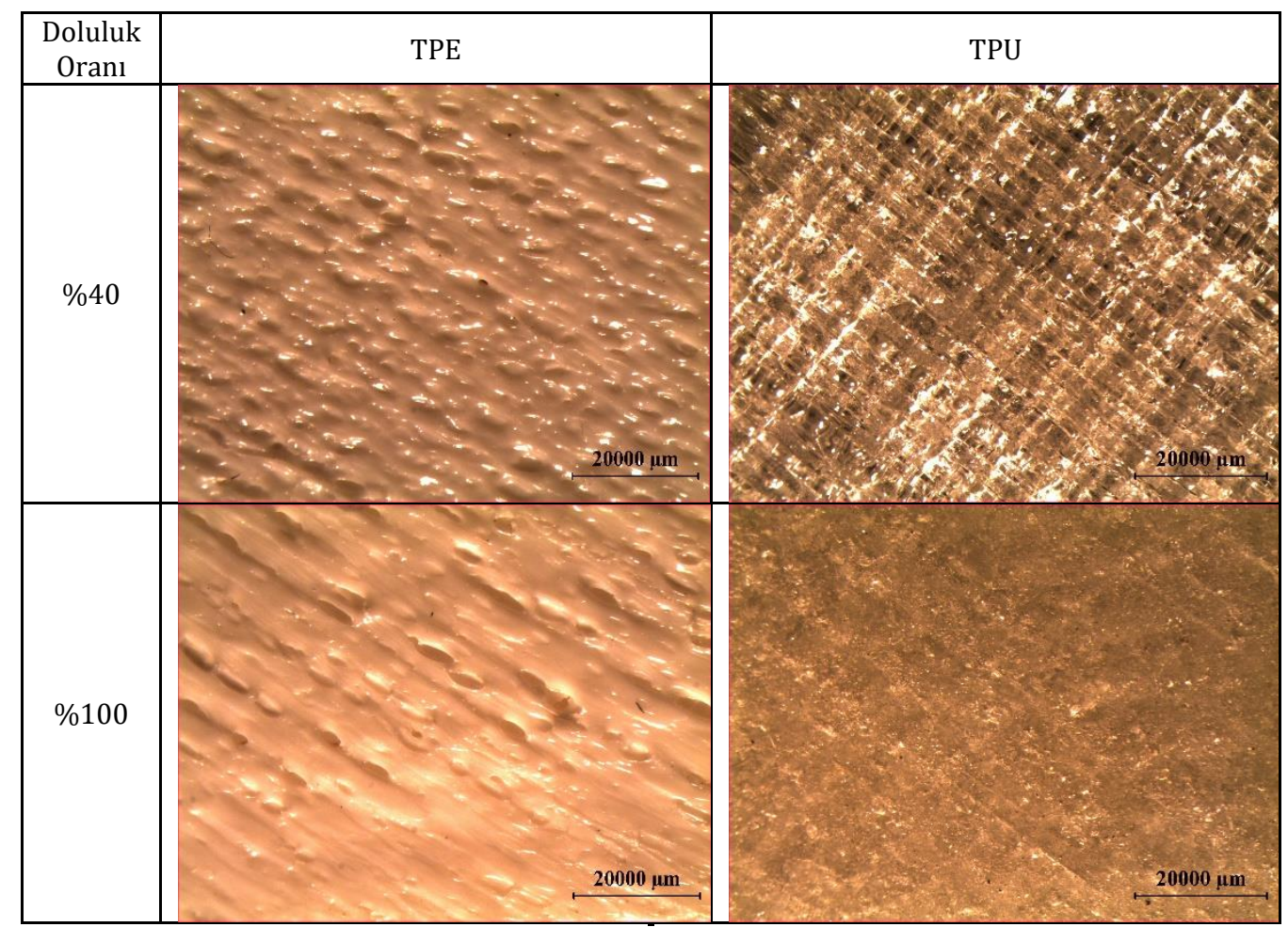

Şekil 12. TPE ve TPU numunelerin yüzey pürüzlülük optik görüntüleri

Şekil 12.'de yüzey pürüzlülük ölçümleri yapılan TPE ve TPU numunelerin üst yüzeylerinden alınan optik mikroskop görüntüleri yer almaktadır. Optik mikroskop görüntüleri incelendiğinde hem TPE hem de TPU malzemeden üretilen $\% 40$ doluluk oranına sahip numunelerin yüzeylerinin $\% 100$ doluluk oranına sahip numunelerin yüzeylerine göre daha pürüzlü olduğu görülmektedir. Ayrıca TPU malzemeyle üretilen numunelerde doluluk oranı arttıkça yüzey pürüzlülügünün azaldığı daha net görülmektedir. Bu durum yüzey pürüzlülük ölçümlerini ve mekanik test sonuçlarını destekler niteliktedir.

\section{Sonuçlar}

Bu çalışmada TPU ve TPE malzemeler 3 boyutlu yazıcıda kullanarak, doluluk oranlarının mekanik özelliklere olan etkisi karşılaştırılmıştır. Bu çalışmadan elde edilen sonuçlar aşağıda verilmiştir.

- Yapılan çekme ve basma testleri sonucunda TPE malzemeden yazdirılan numunelerde doluluk oranlarının artmasıyla birlikte numunenin çekme ve basma gerilmelerinin doğru orantılı olarak arttığı görülmüştür. Aynı zamanda numunelerin yüzde uzama değerleri ve sertlik değerleri de artmıştır. TPE'de en büyük çekme ve kopma gerilmeleri \%100 doluluk oranına sahip numunede elde edilmiştir.

- TPU malzemede ise doluluk oranı \%80'e ulaşıncaya kadar çekme, kopma ve basma gerilmeleri artmış, doluluk oranı arttırılıp \%100'e ulaștığında gerilme değerlerinde azalma olduğu görülmüştür. TPU malzemenin mekanik testlerinde karşılaşılan bu tutarsızlığın nedeninin 3B yazıcıda numune yazdırmak için tercih edilen parametreler olduğu düşünülmektedir. $\mathrm{Bu}$ durum literatürle de desteklenmiştir. TPU malzeme sıcaklığa duyarlı ve termal stabilitesi düşük olan bir malzeme olduğundan yazdırma parametresi olarak tercih edilen $230^{\circ} \mathrm{C}$ sicaklıkta malzeme özelliklerini kaybetmeye, mekanik özelliklerde tutarsızlıklar görülmeye başlanmıştır. TPU malzemenin sertlik değerleri de çekme ve basma test sonuçlarını destekler niteliktedir. TPU malzemede en büyük çekme, kopma ve basma gerilmeleri \%80 doluluk oranına sahip numunelerde elde edilirken, en küçük gerilme değerlerine $\% 40$ doluluk oranına sahip numunelerde rastlanmıștır.

- Polimerik malzemelerde doluluk oranının artması yazıcı nozul ucunun izleyeceği yol 
DEU FMD 21(63), 793-804, 2019

sayısının da artması demektir. Dolayısıyla doluluk oranı arttıkça malzmelenin yüzey pürüzlülüğü de artmaktadır. Artan yüzey pürüzlülüğü malzemelerin üzerinde çentik etkisi yaratabilmekte ve mekanik değerlerini düşürebilmektedir. Ancak gerçekleştirilen çalıșmada kullanılan TPE ve TPU esnek filament malzemelerinde bu durum söz konusu olmamış, doluluk oranı arttıkça yüzey pürüzlülüğü değerleri azalmış, malzemelerin mekanik özellikleri de bu durumdan olumlu etkilenmiștir. Doluluk oranı arttıkça yüzey pürüzlülüğünün azaldığı optik mikroskop görüntülerinden de görülmektedir.

- Diğer taraftan basma testi sonucunda numuneler üzerinden elde edilen boyutsal değișimlere göre hesaplanan orjinal sapma yüzdelerine göre en az orjinallik sapma yüzdesi \%100 doluluk oranına sahip TPE numunelerde rastlanmıștır. Bu durum tercih edilen yazdırma parametrelerinin TPU malzemenin üzerinde olumsuz etki yarattığını, TPE malzemeden elde edilen numunelerin daha güvenilir sonuçlar verdiğini göstermektedir.

\section{Kaynakça}

[1] Celik, D., Cetinkaya, K. 2016. Üc Boyutlu Yazıcı Tasarımları, Prototipleri Ve Ürün Yazdırma Karşılaştırmaları, İleri Teknoloji Bilimleri Dergisi, Cilt 5, s. 151-163.

[2] Atagür, M. 2016. Farklı Yapıya Sahip Kil Mineralleri İle TPU (Termoplastik Poliüretan) Kullanılarak Polimer Matrisli Kompozit Malzeme Üretimi ve Karakterizasyonu. Dokuz Eylül Üniversitesi, Fen Bilimleri Enstitüsü, Yüksek Lisans Tezi, 74s, İzmir.

[3] Can, C., 2008. Plastik Enjeksiyon Kalıplamada Termoplastik Malzemelerin Modelleme Ve Analizleri. Trakya Üniversitesi, Fen Bilimleri Enstitüsü, Yüksek Lisans Tezi, 140s, Trakya.

[4] Kurt, H., 2018. Yeni sanayi ve üretim devrimi, 3 Boyutlu Yazıclar. http://www.ka.net.tr/haberdetay.asp?Id=7\&haber=[-makale-]-yeni-sanayi-veuretim-devrimi-3-boyutlu-yazicilar (Erişim Tarihi: 28.02.2019)

[5] Çelik, D., 2015. Üç Boyutlu Yazıcı Tasarımı, Prototipi Ve Tersine Mühendislik Uygulamaları. Karabük Üniversitesi, Fen Bilimleri Enstitüsü, Yüksek Lisans Tezi, Karabük.

[6] Frick, A., Rochman, A., 2004. Characterization of TPU-elastomers by thermal analysis (DSC), Polymer Testing, Cilt 23, s. 413-417.

[7] Dirim, A., 2015. Esnek Filament ile ve Esnek Reçine Üretim https://www.tasarimdanimalata.com/esnekfilament-ve-esnek-recine-ile-uretim/ (Erişim Tarihi: 28.02.2019)

[8] Yiğit, C.. 2014. Geleceğin Teknolojisi 3B ve 3B yazıcılar. Http://Www.Elektrikport.Com/TeknikKutuphane/Gelecegin-Teknolojisi-3B-Ve-3B-
Printerlar/14485\#Ad-İmage-0 (Erișim Tarihi: 28.02.2019)

[9] 3B yazıcl ile protez üretimi http://www.prototip.org/3B-yazici-ile-protezuretimi/ (Erişim Tarihi: 28.02.2019)

[10] Tabuani, D., Bellucci, F., Terenzi, A., Camino, G., 2012. Flame retarded Thermoplastic Polyurethane (TPU) for cable jacketing application, Polymer Degradation and Stability, Cilt 97, s. 2594-2601.

[11] Günay M., Gündüz S., Yılmaz H., Yaşar N. ve Kaçar R., *. PLA esaslı numunelerde çekme dayanımı için 3D baskı işlem parametrelerinin optimizasyonu, Politeknik Dergisi, cilt*, s. *

[12] Chacon J.M., Caminero M.A., Garcia-Plaza E. and Nunez P.J., 2017. Additive manufacturing of PLA structures using fused deposition modelling: Effect of process parameters on mechanical properties and their optimal selection, Materials and Design, Cilt: 124, s 143-157.

[13] Xiao, J., Gao, Y., 2017. The manufacture of 3B printing of medical grade TPU, Progress in Additive Manufacturing, Cilt 2, s 117-123.

[14] Evlen H., Özdemir M. A. ve Çalışkan A., *. Doluluk Oranlarının PLA ve PET malzemelerin mekanik özellikleri üzerine etkileri, Politeknik Dergisi, *, s. *.

[15] Semen, B.S., Turan, A., Çakır, O., 2018. Termoplastik Üretan ve Termoplastik Elastomer Malzemelerin Eklemeli İmalat Teknolojilerinde Kullanım ve Mekanik Özelliklerinin İncelenmesi. Karabük Üniversitesi, Teknoloji Fakültesi, Lisans Tezi, 65s, Karabük

[16] DIN EN IS01798-2008, Flexible cellular polymeric materials -Determination of tensile strength and elongation at Break https://edoc.site/din-en-iso1798-2008-pdfpdf-pdf-free.html (Erişim Tarihi: 01.03.2019)

[17] ASTM International D395-03, Standard Test Methods for Rubber Property-Compression Set Method

http://file.yizimg.com/175706/20110909093542 25.pdf (Erişim Tarihi: 01.03.2019)

[18] Hary'nska, A., Gubanska, I., Kucinska-Lipka, J., Janik, H., 2018. Fabrication and Characterization of Flexible Medical-Grade TPU Filament for Fused Deposition Modeling 3BP Technology, Polymers, s 1-19.

[19] Evlen, H., Özdemir, M.A., Çalıșkan, A., 2019. Doluluk oranlarının PLA ve PET malzemelerin mekanik özellikleri üzerine etkileri, Politeknik Dergisi, *, s.*

[20] Göztaş, Z., Tosun, G., Yıldız, E. and Kahraman, K., 2014. Nano doldurucu içeren beş farklı kompozitin yüzey sertliği ve pürüzlülüğ̈̈ açısından değerlendirilmesi, Selcuk Dental Journal, Cilt 2, s. 43-48.

[21] Özel, C. and Baydar, U. 2016. Onarım Ve Güçlendirmede Kullanılan Polimer Betonların Aderans Özelliklerinin Beton Yüzey Karakteristikleri İle İliskileri, SDU International Journal of Technological Science, Cilt 8, s 46-61. 